\title{
Surgical treatment of pulmonary metastases
}

\author{
G. M. REES and W.P. CLELA N D \\ Department of Surgery, Brompton Hospital, London S.W.3
}

Isolated pulmonary metastases from many primary sources were treated by surgery in 37 patients. Twenty-one per cent of those with carcinomas and $16 \%$ of those with sarcomas survived for five years. Twenty-four patients are now dead, 21 from generalized tumour dissemination. Occasional long-term survivals were obtained which, when related to the low mortality and morbidity attending thoracotomy, make this form of therapy worthy of consideration in selected cases.

The development of pulmonary metastases is generally a sign of widespread tumour dissemination and is associated with a poor prognosis (Rubin and Green, 1968). Nevertheless, in recent years there have been a number of reports describing long-term survival following the surgical resection of localized metastases (Alexander and Haight, 1947 ; Wilkins, Burke, and Head, 1961; Thomford, Woolner, and Clagett, 1965; Sellors, 1970). This paper details the results obtained in a group of patients with lung secondaries from a wide variety of primary tumours; the diagnosis of pulmonary metastases was made preoperatively in every case.

\section{PATIENTS AND METHODS}

Altogether 37 patients are described (aged 11 to 76 years). In most cases the pulmonary metastases were solitary. All the primary tumours had been removed

\section{T A B LE I}

DISTRIBUTION OF PRIMARY TUMOURS METASTASIZING

\begin{tabular}{|c|c|c|c|c|}
\hline \multirow{2}{*}{\multicolumn{2}{|c|}{ Site }} & \multirow[t]{2}{*}{ No. } & \multicolumn{2}{|c|}{$\begin{array}{l}\text { Interval (yr) between } \\
\text { Original Operation } \\
\text { and Thoracotomy }\end{array}$} \\
\hline & & & Mean & Range \\
\hline 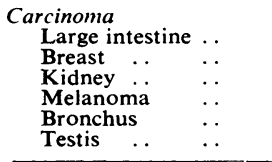 & $\begin{array}{l}\cdots \\
\cdots \\
\cdots \\
\cdots \\
\cdots\end{array}$ & $\begin{array}{l}5 \\
3 \\
6 \\
2 \\
2 \\
9\end{array}$ & $\begin{array}{l}4 \frac{1}{2} \\
2 \\
5 \frac{1}{2} \\
9 \\
5 \frac{1}{2} \\
1 \frac{1}{2}\end{array}$ & $\begin{array}{l}2-6 \\
0-3 \\
\frac{1}{3}-17 \\
9-10 \\
4-7 \\
0-4\end{array}$ \\
\hline $\begin{array}{l}\text { Sarcoma } \\
\text { Fibrosarcoma . . } \\
\text { Chondrosarcoma } \\
\text { Osteosarcoma . } \\
\text { Malignant synovioma }\end{array}$ & $\begin{array}{l}\cdots \\
\cdots \\
\cdots\end{array}$ & $\begin{array}{l}5 \\
1 \\
1 \\
1\end{array}$ & $\begin{array}{r}4 \frac{1}{2} \\
14 \\
4 \\
4 \\
\end{array}$ & $1 \frac{1}{2}-12$ \\
\hline $\begin{array}{l}\text { Miscellaneous } \\
\quad \text { Meningioma } \ldots \\
\text { Chemodectoma.. }\end{array}$ & 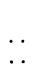 & $\begin{array}{l}1 \\
1\end{array}$ & $1^{\frac{1}{2}}$ & \\
\hline
\end{tabular}

before the patients were referred to us. The patients are grouped according to the type and location of the primary tumour indicating the interval between the original operation and thoracotomy (Table I). A careful search was instituted for evidence of other metastases before recommending the thoracotomy, but ? undue delay was avoided.

In the present series, four patients had pneumonectomies, 18 had lobectomies, four had segmental resection, and eight a wedge resection. In two, lobectomy was combined with wedge resections for multiple metastases while in a further patient segmental resection of one lobe was combined with removal of another.

\section{RESULTS (Table II)}

Thirty-nine operations were carried out on 37 patients. In one patient bilateral metastases were removed on separate occasions, while in another local recurrence following lobectomy was treated by pneumonectomy. In two cases $(5 \%)$ death was directly attributable to operation, in one from a postoperative pulmonary embolus ; another died of haemorrhage.

Twenty-four patients out of a total of 37 are $\frac{D}{0}$ now dead, 21 from generalized metastases. In only one case, the malignant synovioma, was there a $N$ local pulmonary recurrence.

Following resection of metastatic carcinomas $92 \%$ of patients were alive one year later; after five $\omega$ years $21 \%$ were alive. In the case of sarcomas, $75 \%$ survived one year, while $16 \%$ survived five years.

\section{DISCUSSION}

In the majority of cases in this series pulmonary metastases were detected by routine chest radio- $\mathbb{\mathbb { Q }}$ graphs when the patients were asymptomatic. The 
T A B LE I I

RESULTS OF THORACOTOMY

\begin{tabular}{|c|c|c|c|c|c|c|c|}
\hline \multirow[b]{2}{*}{ Site } & \multirow[b]{2}{*}{ No. } & \multirow[b]{2}{*}{$\begin{array}{l}\text { Operative } \\
\text { Death }\end{array}$} & \multicolumn{3}{|c|}{ Late Deaths } & \multicolumn{2}{|r|}{ Alive } \\
\hline & & & No. & Cause & $\begin{array}{l}\text { Post-thoracotomy } \\
\text { Survival (yr) }\end{array}$ & No. & $\begin{array}{l}\text { Post-thoracotomy } \\
\text { Survival (yr) }\end{array}$ \\
\hline $\begin{array}{l}\text { Carcinoma } \\
\text { Large intestine } \\
\text { Breast } \\
\text { Kidney } \\
\text { Melanoma } \\
\text { Bronchus } \\
\text { Testis }\end{array}$ & $\begin{array}{l}5 \\
3 \\
6 \\
2 \\
2 \\
9\end{array}$ & $\begin{array}{l}1 \\
- \\
- \\
-\end{array}$ & $\begin{array}{l}3 \\
2 \\
4 \\
2 \\
2 \\
3\end{array}$ & $\begin{array}{cc}\text { Widespread dissemination } \\
\text {," } \\
\text {," } \\
\text {," } \\
\text {," }\end{array}$ & $\begin{array}{l}3,3,2 \\
3,3 \\
3,2 \frac{1}{2}, 4 \frac{1}{2}, 2 \\
<1,<1 \\
3,5 \\
<1,1,<1\end{array}$ & $\begin{array}{l}1 \\
1 \\
2 \\
\overline{6}\end{array}$ & $\begin{array}{l}3 \\
10 \\
<1,4 \\
- \\
\overline{2} \frac{1}{2}, 13,13,12,3,<1\end{array}$ \\
\hline $\begin{array}{l}\text { Sarcoma } \\
\text { Fibrosarcoma } \\
\text { Chondrosarcoma } \\
\text { Osteosarcoma } \\
\text { Malignant } \\
\quad \text { synovioma }\end{array}$ & $\begin{array}{l}5 \\
1 \\
1 \\
1\end{array}$ & $\begin{array}{l}1 \\
- \\
-\end{array}$ & $\begin{array}{l}3 \\
1 \\
1 \\
-\end{array}$ & \begin{tabular}{cc}
\multicolumn{3}{c}{ Widespread dissemination } \\
," ," \\
,, ,"
\end{tabular} & $\begin{array}{l}<1,<1,<1 \\
2 \\
-\end{array}$ & $\begin{array}{l}1 \\
- \\
1\end{array}$ & 2 \\
\hline $\begin{array}{l}\text { Miscellaneous } \\
\text { Meningioma } \\
\text { Chemodectoma }\end{array}$ & $\begin{array}{l}1 \\
1\end{array}$ & $\overline{-}$ & $\frac{1}{-}$ & Cerebral infarct & $\begin{array}{l}3 \\
-\end{array}$ & $\overline{1}$ & 6 \\
\hline Total & 37 & 2 & 22 & & & 13 & \\
\hline
\end{tabular}

importance of frequent postoperative radiographs has been previously emphasized (Asvall, Sanderud, and Nitter, 1967). Tomography was also carried out in most patients, but in our experience it has rarely added to information provided by good quality plain radiographs. The timing of surgical intervention is controversial. Asvall et al. (1967) recommend operation as soon as pulmonary metastases are diagnosed provided there is no evidence of additional secondaries. Others (Clagett and Woolner, 1964) advise a few months' observation to ensure, as far as possible, the absence of widespread dissemination. In general, we have tended towards the latter view, although undue delay in recommending surgery was considered to be unjustifiable.

Initially, it was felt that the extent of resection for metastases should be similar to that employed in the treatment of primary bronchial carcinoma, that is, removal of a lung or lobe complete with its related lymph nodes. We now feel that preservation of lung tissue is important as local recurrence is unusual -in this series on one occasion onlyand resection for further secondary deposits may be required at a later date (Cleland, 1967 ; Sellors, 1970).

Resection of metastases from testicular teratomas may be attended by very encouraging results; these have been fully documented elsewhere (Rees and Cleland, 1971). In these cases optimum results are obtained by combining chemotherapy, radiotherapy, and surgery. The metastases themselves may have unusual growth and invasive characteristics (Smithers, 1969) and may show higher differentiation histologically than the primary tumours (Rees and Cleland, 1971).

Removal of secondaries from breast carcinomas is said to give disappointing results and should rarely be attempted (Rubin and Green, 1968). One of three patients in this series is, however, alive and free of recurrence more than 10 years after thoracotomy; the metastasis was noted to be present at the time of radical mastectomy. Metastases from renal and large intestinal tumours were attended with indifferent long-term results. In the former cases, four out of six are dead, the mean survival being nearly three years, while in the group of large gut tumours four out of five have died. Wilkins et al. (1961) produced five-year survival figures of $31 \%$ and $18 \%$, respectively, following resection of pulmonary metastases from renal and colonic carcinomas. Resection of metastases from bronchial carcinomas was followed by an appreciable survival although both patients ultimately died of further recurrence. Such operations present a particularly intricate problem and emphasize the importance of a limited resection on the second occasion, particularly as in one patient the original operation was a pneumonectomy. In the second patient the original operation was an upper lobectomy combined with sleeve resection, which in many cases results in preservation of excellent lung function (Rees and Paneth, 1970).

Most series indicate that the outlook following resection of pulmonary metastases is more favourable in the case of carcinomas than sarcomas (Moersch and Clagett, 1961 ; Ochsner, Clemmons, and Mitchell, 1963). Few large series have, however, been reported and the number of cases of a particular type of tumour is necessarily small while the role of case selection is of great importance. Thus Alexander and Haight (1947) found the prognosis better with sarcomas than carcinomas. In the 
present heterogeneous series carcinomas fared better than sarcomas, although one patient with a chondrosarcoma and one with a malignant synovioma had worthwhile survival times. Two rare cases included are those of the pulmonary metastasis from a meningioma and multiple metastases from an aortic chemodectoma. Multiple wedge resections at two separate thoracotomies were undertaken in the latter case (le Brun, Cleland, and Smithers, 1967).

Whether the interval between removal of the primary tumour and discovery of metastases is related to prognosis is controversial (Gliedman, Horowitz, and Lewis, 1957 ; Wilkins et al., 1961). Clarification of this point in a small series is difficult. If this premise is correct, the outlook should be better in a group of patients, as described, where the metastases appeared a considerable time after the first operation; we believe that our results do not support such a conclusion.

Our overall experience is in agreement with that claimed by others (Rubin and Green, 1968). Although the outlook following resection of pulmonary metastases is generally poor-most patients eventually died of widespread disseminationoccasional long-term survivals are obtained. The associated low mortality and morbidity thus make this a form of treatment which merits consideration in selected cases.

Most of these patients were referred to the Joint Neoplastic Clinic, Brompton Hospital, by the physicians and surgeons of the Brompton and Royal Marsden Hospitals. We gratefully acknowledge their co-operation.

\section{REFERENCES}

Alexander, J., and Haight, C. (1947). Pulmonary resection for solitary metastatic sarcomas and carcinomas. Surg. Gynec. Obstet., 85, 129.

Asvall, J., Sanderud, A., and Nitter, L. (1967). Treatment of isolated lung metastases. Acta radiol. Ther. Phys. Biol., 6, ָิ 351.

le Brun, H. I., Cleland, W. P., and Smithers, D. W. (1967). $\vec{\circ}$ Chemodectoma in the region of the aortic bifurcation. Brit. J. Surg., 54, 807.

Clagett, O. T., and Woolner, L. B. (1964). Surgical treatment of solitary metastatic pulmonary lesion. Med. Clin. N. Amer., 48, 939.

Cleland, W. P. (1967). In: Proceedings on the Symposium on Chest Diseases, edited by L. G. Topham, p. 254. R.N. ? Hospital, Haslar. Eli Lilly, Basingstoke.

Gliedman, M. L., Horowitz, S., and Lewis, F. J. (1957). Lung resection for metastatic cancer. Surgery, 42, 521.

Moersch, R. N., and Clagett, O. T. (1961). Pulmonary resection for metastatic tumors of the lungs. Surgery, $Z$ 50, 579.

Ochsner, A., Clemmons, E. F., and Mitchell, W. T. (1963). The treatment of metastatic pulmonary malignant lesions. Journal Lancet, 83, 16.

Rees, G. M., and Cleland, W. P. (1971). Surgical treatment of pulmonary metastases from testicular tumours. Brit. med. J., 3, 467.

- , and Paneth, M. (1970). Lobectomy with sleeve resection in the treatment of bronchial tumours. Thorax, 25, 160.

Rubin, P., and Green, J. (1968). Solitary Metastases, p. 9. Charles C. Thomas, Springfield, Illinois.

Sellors, T. H. (1970). Treatment of isolated pulmonary metastases. Brit. med. J., 2, 253.

Smithers, D. W. (1969). Maturation in human tumours. Lancet, 2, 949.

Thomford, N. R., Woolner, L. B., and Clagett, O. T. (1965). The surgical treatment of metastatic tumors in the lungs. J. thorac. cardiovasc. Surg., 49, 357.

Wilkins, E. W., Burke, J. F., and Head, J. M. (1961). The surgical management of metastatic neoplasms in the lung. J. thorac. cardiovasc. Surg., 42, 298. 